\title{
ECUT Energy Data Reference Series: Lightweight Materials for Ground Transportation
}
R. B. Abarcar
G. J. Hane
D. R. Johnson

July 1984

Prepared for the U.S. Department of Energy under Contract DE-AC06-76RLO 1830

Pacific Northwest Laboratory Operated for the U.S. Department of Energy by Battelle Memorial Institute 


\title{
DISCLAIMER
}

This report was prepared as an account of work sponsored by an agency of the United States Government. Neither the United States Government nor any agency thereof, nor any of their employees, makes any warranty, express or implied, or assumes any legal liability or responsibility for the accuracy, completeness, or usefulness of any information, apparatus, product, or process disclosed, or represents that its use would not infringe privately owned rights. Reference herein to any specific commercial product, process, or service by trade name, trademark, manufacturer, or otherwise, does not necessarily constitute or imply its endorsement, recommendation, or favoring by the United States Government or any agency thereof. The views and opinions of authors expressed herein do not necessarily state or reflect those of the United States Government or any agency thereof.

\author{
PACIFIC NORTHWEST LABORATORY \\ operated by \\ BATTELLE \\ for the \\ UNITED STATES DEPARTMENT OF ENERGY \\ under Contract DE-AC06-76RLO 1830
}

\begin{tabular}{|c|c|}
\hline \multirow{2}{*}{\multicolumn{2}{|c|}{ Printed in the United States of America }} \\
\hline & \\
\hline \multicolumn{2}{|c|}{$\begin{array}{l}\text { Avallable from } \\
\text { ional Technical Information Service }\end{array}$} \\
\hline \multirow{3}{*}{\multicolumn{2}{|c|}{$\begin{array}{l}\text { United States Department of Commerce } \\
5285 \text { Port Royal Road } \\
\text { Springfield, Virginia } 22161\end{array}$}} \\
\hline & \\
\hline & \\
\hline \multicolumn{2}{|c|}{$\begin{array}{l}\text { NTIS Price Codes } \\
\text { Microfiche A01 }\end{array}$} \\
\hline & \\
\hline \multicolumn{2}{|c|}{ Printed Copy } \\
\hline & Price \\
\hline Pages & Codes \\
\hline $001-025$ & $\mathrm{~A} 02$ \\
\hline 026-050 & $\mathrm{A} 03$ \\
\hline 051-075 & A04 \\
\hline 076-100 & A05 \\
\hline $101-125$ & A06 \\
\hline $126-150$ & $\mathrm{~A} 07$ \\
\hline $151-175$ & $A 08$ \\
\hline $176-200$ & A09 \\
\hline 201-225 & A010 \\
\hline $226-250$ & A011 \\
\hline $251-275$ & A012 \\
\hline $276-300$ & A013 \\
\hline
\end{tabular}


ECUT ENERGY DATA REFERENCE SERIES:

LIGHTWEIGHT MATERIALS FOR GROUND TRANSPORTATION

R. B. Abarcar (a)

G. J. Hane

D. R. Johnson

July 1984

Prepared for Energy Conversion and Utilization Technologies Division Office of Energy Systems Research Conservation and Renewable Energy U.S. Department of Energy under Contract DE-ACO6-76RLO 1830

Pacific Northwest Laboratory

Richland, Washington 99352

(a) Energetics, Inc. Columbia, Maryland 21045 

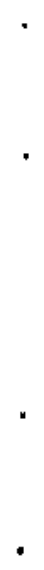

• 


\section{ACXNOWLEDGMENTS}

This series was a substantial undertaking that even now would not be accomplished were it not for the significant efforts of Dan Johnson. Dan saw the obstacles in data gathering, report writing, and finally publication. In the later stages of this work, Judy Danko provided critical editorial assistance and encouragement. It was through her efforts that all the volumes of this series were completed and published simultaneously.

D. L. Brenchley

Project Manager 


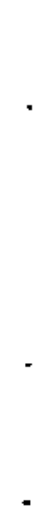




\section{PREFACE}

This study was completed for the Division of Energy Conversion and Utilization Technologies (ECUT) in the Department of Energy. The division's mission has three parts:

1. to monitor advances in basic scientific research and evaluate them for their applicability to energy conservation

2. to perform exploratory development on novel or innovative conservation concepts

3. to expand the technology base for advanced conservation technologies. To aid in achieving this mission the ECUT staff established a planning and systems analysis function to identify and assess the array of opportunities for energy conservation R\&D.

This on-going activity provides ECUT Staff with the information necessary to decide where to invest limited research dollars to derive the maximum benefit to the public. As part of its systems analysis role for ECUT, PNL published a general energy use data book covering all major end-use sectors (Imhoff, Liberman, and Ashton 1982). In contrast, the current ECUT Energy Data Reference Series is more narrowly targeted; each volume contains detailed capital stock and energy-use data for selected end-use sectors that are likely to be most impacted by existing or proposed ECUT R\&D activities.

This volume relates to lightweight materials for ground transportation. Research in this area would investigate techniques to alloy magnesium and to measure the properties of such alloys. In addition, the feasibility of creating and using metal matrix composites would be investigated. These efforts would be directed at reducing the weight of the vehicie.

Other volumes in the ECUT Energy Data Reference Series include:

Hane, G. J. and 0. R. Johnson. 1984. ECUT Energy Data Reference Series: Otto Cycle Engines in Transportation. PNL-5191, Pacific Northwest Laboratory, Richland, Washington. 
Abarcar, R. B., G. J. Hane and D. R. Johnson. ECUT Energy Data Reference Series: High-Temperature Materials for Advanced Heat Engines. PNL-5193, Pacific Northwest Laboratory, Richland, Washington.

Young, J. K. and D. R. Johnson. 1984. ECUT Energy Data Reference Series: Ammonia Synthesis Energy Use and Capital Stock Information. PNL-5194, Pacific Northwest Laboratory, Richland, Washington.

Chockie, A. D. and D. R. Johnson. 1984. ECUT Energy Data Reference Series: Boilers. PNL-5195, Pacific Northwest Laboratory, Richland, Washington.

The bulk of the research for this series was conducted in calendar year 1982. While the data portrayed in these publications have not changed dramatically, certain trends, particularly those that were forecast, may have shifted in the interim between research and publication.

The ECUT Data Reference Series is part of a series of studies in support of the ECUT research planning effort. Other ECUT publications are:

Bomelburg, H. J. 1983. Efficiency Evaluation of Oxygen Enrichment in Energy Conversion Processes. PNL-4917, Pacific Northwest Laboratory, Richland, Washington.

Chockie, A., et al. 1983. "An Overview of Research Requirements for Stationary Combustion Systems." In Proceedings of the 18th Intersociety Energy Conversion Engineering Conference, pp. 2092-2098. American Institute of Chemical Engineers, $345 \mathrm{E} .47 \mathrm{St}$., New York, New York.

Hane, G. 1983. Efficiency Evaluation of the DISC, DHC, and DI Diesel Engines. PNL-4568, Pacific Northwest Laboratory, Richland, Washington.

Hane, G., et al. 1983. A Preliminary Overview of Innovative Industrial Materials Processes. PNL-4505, Pacific Northwest Laboratory, Richland, Washington.

Hane, G., et al. 1984. A Review of Studies of Research Opportunities in Energy Conservation. PNL-4571, Pacific Northwest Laboratory, Richland, Washington.

Hopp, w., et al. 1981. An Overview of Energy Conservation Research Opportunities--Executive Summary. PNL-3944 Ex. Sum., Pacific Northwest Laboratory, Richland, Washington.

Hopp, w., et al. 1981. An Overview of Energy Conservation Research Opportunities. PNL-3944, Pacific Northwest Laboratory, Richland, Washington.

Hopp, W., et al. 1982. Identification of Energy Conservation Research Opportunities: A Review and Synthesis of the Literature. PNL-3966, Pacific Northwest Laboratory, Richland, Washington. 
U.S. Department of Energy. 1981. The 1981 ECUT Work Element Appraisal. $\mathrm{DOE} / \mathrm{CE}-0 \mathrm{D24}$, U.S. Department of Energy, Washington, D. C.

U.S. Department of Energy. 1983. Energy Conversion and Utilization Technologies Program Report, 1981-1982. U.S. Department of Energy, Washington, D.C.

Vallario, R. W. and D. E. DeBellis. 1984. State of Technology of Direct Contact Heat Exchanging. PNL-5008, Pacific Northwest Laboratory, Richland, Washington.

Vitullo, M., C. Winter and D. R. Johnson. 1984. The Executive Information System. PNL-5190, Pacific Northwest Laboratory, Richland, Washington. 


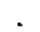


BACKGROUND ON ECUT ENERGY DATA REFERENCE SERIES

The ECUT Energy Oata Reference Series defines and assesses in quantitative terms the potential markets for expected ECUT R\&O results. Each volume in the series provides data on a particular class of hardware systems that use and convert fuel. The data for each system include inventories of energy capital stocks, specific fuels consumption and product or service activity levels for the years 1980 and 200D, and average thermal efficiencies. Each data set characterizes the capital stock in a sector or subsector of the U.S. economy to which expected results from ECUT R 80 projects can be applied. Each reference volume is consistent with the others in the series in format and approach, thus forming a framework for comparing certain aspects of ECUT R\&D activities.

The ECUT Energy Data Reference Series serves as a benchmark for energy consumption and for conservation data for technologies addressed by the ECUT Program. The series incorporates the most accurate and up-to-date projections available in the open literature on energy capital stocks and their consumption levels. The series is specifically intended to be one of the many planning tools ECUT management can use to assess what potential impact its research projects will have. The series can also be used to demonstrate the potential impact of research on various stakeholders and constituencies, including industrial interest groups, budget decision makers, and the general public.

METHODOLOGY

The ECUT Energy Data Reference Series synthesizes data from the open literature, including technical reports, results of techno-economic models, industry surveys, and trade journal publications. A specific format was developed around the data items of interest and the intended purpose of the series. Each volume deals with a unique R\&D application. Two scenarios are described--a baseline for 1980 and a projection for 2000 .

The first line of effort is to extract the most recent data that are already in usable form in the open literature. In the case of competing data from disparate sources, the most reliable data are selected on the basis of the 
completeness and extensiveness of the research. Where data sources appear to be equally reliable, an averaging method is employed to derive a single data point.

The second line of effort is to derive or extrapolate the needed data from the literature. For instance, if no energy consumption data are reported, production data can be multiplied by energy intensity data to derive consumption data.

Certain assumptions are used in projecting data points to the year 2000 . The general rule is that the status quo is maintained throughout the projected future unless otherwise specified in the text. The energy capital stock is assumed to remain at its 1980 state of technology, and no competing technologies are considered to capture market share. This is in keeping with the objective of defining the potential impact of $R \& D$ results. In characterizing systems or processes with multiple fuel inputs, the mix of conventional fuels (those commonly used today) is allowed to change as each fuel is impacted by obvious and compelling factors, but no alternative, non-conventional fuels are projected as part of the fuel mix.

For simplicity, electricity is considered to be a fuel. This allows for a discussion of capital stocks that use electricity as an input without going through the machinations of breaking out power generation inputs, transmission losses, etc. These factors are considered to be constant at the national average, and are readily available in the literature.

\section{$\underline{\text { SCOPE }}$}

The scope is defined along two directions: the data items of interest, and the end-use sector applications for ECUT R\&D activities. The data items of interest, described below, are essential to a basic perspective on the potential impact of expected ECUT R\&D results. Data items that change with time are defined for the year 1980 and projected for the year 2000. 


\section{DATA ITEMS}

The data items considered in this series of reports are unit process hardware systems, efficiency estimates, capital stock information, fuel consumption demand, and product or service activity level.

Unit Process Hardware System

A unit process hardware system (UPHS) is generally defined as the least extensive configuration of components in a conversion or utilization system to which R\&D results can be applied, and for which efficiency and fuel consumption estimates can be made. A UPHS is uniquely defined for each sector potentially impacted by ECUT R\&D activity.

\section{Efficiency Estimates}

A specific definition of efficiency is developed for each application of each R\&D activity. In general, the definition is based on the first law of thermodynamics, and is applied to the UPHS of interest. A broad discussion of major efficiency-loss mechanisms is included in each section on efficiency. Capital Stock Information

Data derived for 1980 and projected for 2000 are based on the number of UPHSs in the economy that would be potential recipients of ECUT R\&D results. UPHSS are disaggregated according to the type of fuel they use or convert. Other factors that help characterize the capital stock as a market for ECUT research are included as necessary and/or available.

\section{Fuel Consumption Demand}

Fuel consumption demand is developed for 1980 and projected for 2000 . The thermal energy value (measured in Btu) of each fuel type consumed or converted by the capital stock of interest is developed for each application of each R\&D activity. Electricity is considered to be a fuel. The extent to which use of alternative (non-conventional) fuels will penetrate the end-use sectors of interest by the year 2000 is not predicted. The relative contribution of conventional fuels in use today is, however, allowed to change with the turnover of capital stocks and with trends in consumer preferences. No attempt is made to project the availability of conventional fuels in 2000 . 
Product or Service Activity Level

Data on the demand for each product or service resulting from the use or conversion of energy by the capital stock of UPHSs are developed for 1980 and projected for 2000 . 
This report summarizes information that describes the use of lightweight materials in automobiles. The information on this mode of transportation represents the largest potential energy savings for substitution of lightweight materials in the transportation sector. Included are data on energy conversion efficiency of the engine and its relationship to vehicle weight, the capital stock, the amount of energy used, and the service activity level as measured in ton-miles. This information is summarized in Tables S.1 and S.2.

TABLE S.1. R\&D Applications Summary - Automobiles

\begin{tabular}{|c|c|c|c|c|c|c|c|}
\hline Data Item/ & \multirow{2}{*}{$\begin{array}{c}\text { UPHS } \\
\text { Average } \\
\text { Efficlency } \\
1980\end{array}$} & \multicolumn{2}{|c|}{$\begin{array}{l}\text { Unit Process } \\
\text { Hardware Systems }\end{array}$} & \multicolumn{2}{|c|}{$\begin{array}{c}\text { Fuel Consumption } \\
\text { Demand }(B+u)\end{array}$} & \multicolumn{2}{|c|}{$\begin{array}{l}\text { Product or } \\
\text { vice Activity Levei } \\
\text { (ton-ml les) }\end{array}$} \\
\hline $\begin{array}{l}\text { Data } \\
\text { Fuel } \\
\end{array}$ & & 1980 & 2000 & 1980 & 2000 & 1980 & 2000 \\
\hline Gasoline & 268 & $104,564,000$ & $110,000,000$ & $9,740 \times 10^{12}$ & $7,050 \times 10^{12}$ & $2,060 \times 10^{9}$ & $1,910 \times 10^{9}$ \\
\hline
\end{tabular}

TABLE S.2. Market Data Summary - Automobiles

\begin{tabular}{|c|c|c|c|c|c|}
\hline $\begin{array}{l}\text { Data Item/ } \\
\text { Fuel Type }\end{array}$ & $\begin{array}{c}\text { Total } \\
\text { Unit } \\
\text { Process } \\
\text { Hardware } \\
\text { Systems } \\
\text { T980 }\end{array}$ & $\begin{array}{c}\text { Total Projected } \\
\text { Unit Process } \\
\text { Hordware Systems } \\
\frac{2000}{}\end{array}$ & $\begin{array}{c}\text { UPHS Due } \\
\text { to Industry } \\
\text { Capacity Expan- } \\
\text { slon (Increased } \\
\text { Service Demand) } \\
2000\end{array}$ & $\begin{array}{l}\text { UPHS Due to } \\
\text { Replacement of } \\
\text { Obsolete Units } \\
2000\end{array}$ & $\begin{array}{l}\text { \# UPHS from } \\
1980 \text { Remaining } \\
\text { in Service } \\
2000\end{array}$ \\
\hline Gasoline & $104,564,000$ & $110,000,000$ & $5,436,000$ & $101,427,000$ & $3,136,920$ \\
\hline
\end{tabular}




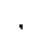


CONTENTS

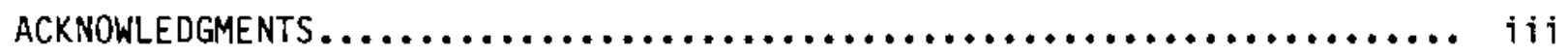

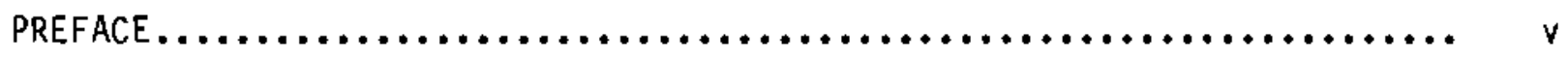

BACKGROUND ON ECUT ENERGY DATA REFERENCE SERIES $\ldots \ldots \ldots \ldots \ldots \ldots \ldots \ldots \ldots$ ix

SUMMARY................................................... xi i

1.0 LIGHTWE IGHT MATERIALS FOR GROUND TRANSPORTATION............... 1.1

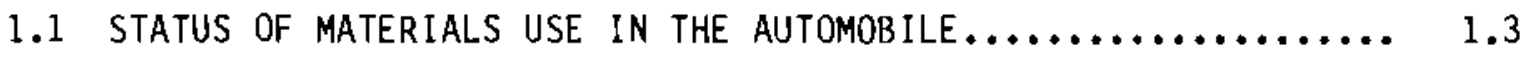

1.2 Efficiency estimate $\ldots \ldots \ldots \ldots \ldots \ldots \ldots \ldots \ldots \ldots \ldots \ldots \ldots \ldots, 1.7$

1.3 CAPITAL STOCK INFORMATION........................... 1.17

1.3.1 Capital Stock Information, $1980 . \ldots \ldots \ldots \ldots \ldots \ldots \ldots . . .1 .17$

1.3 .2 Capital Stock Information, $2000 . \ldots \ldots \ldots \ldots \ldots \ldots \ldots . . . . .21$

1.4 fuel COnSumption demand $, \ldots \ldots \ldots \ldots \ldots \ldots \ldots \ldots \ldots \ldots \ldots, 1.22$

1.4.1 Fuel Consumption Demand, $1980 . \ldots \ldots \ldots \ldots \ldots \ldots \ldots \ldots . . .6 .22$

1.4.2 Fuel Consumption Demand, $2000 \ldots \ldots \ldots \ldots \ldots \ldots \ldots \ldots . . .23$

1.5 SERVICE ACtivity LEVEL............................ 1.23

1.5.1 Service Activity Leve $, 1980 \ldots \ldots \ldots \ldots \ldots \ldots \ldots \ldots \ldots, 1.23$

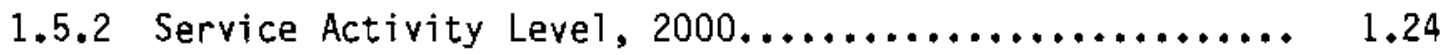

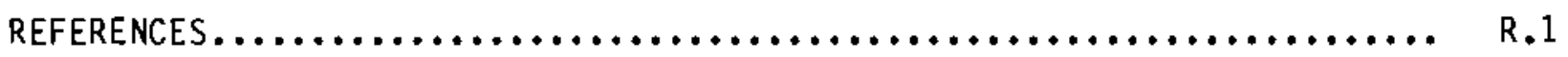




\section{FIGURES}

1.1 Typical Automobile Energy Requirements for the EPA Specified Composite Driving Car................................ 1.2

1.2 Introduction of New Materials for Automotive Applications........ 1.3

1.3 Average Motor Vehicle Material Composition by Weight........... 1.6

1.4 Energy Use in Passenger Car During EPA Cycle.................. 1.11

1.5 Typical Fuel Consumption Map for Dtto-Cycle Engine............. 1.13

1.6 Survival Probability Curves for Automobiles and Light Trucks...... 1.19

\section{TABLES}

S.1 R\&D Applications Summary - Automobiles..................... xiji

S.2 Market Data Summary - Automobiles......................... xii

1.1 Estimated Materials Consumption in a Typical U.S.-Built Car........ 1.4

1.2 Materials in the 1975 Automobile......................... 1.5

1.3 Comparison of Baseline and Goal Material Content in Motor Vehicles........................................ 1.6

1.4 Candidate Alternative Automotive Materials.................. 1.8

1.5 Materials Technology - Illustrative Research Areas.............. 1.9

1.6 Automobile Stock in 1980 by Size Category................... 1.17

1.7 Motor Vehicles in Use, Sales and New Registration in the

1.8 Market Shift in Automobile Sales Between 1978 and 19B0.......... 1.19

1.9 Automobiles in Operation, Scrappage Rates, and Vehicle
Travel by Age of Vehicle, $1980 . \ldots \ldots \ldots \ldots \ldots \ldots \ldots \ldots \ldots \ldots \ldots \ldots \ldots$

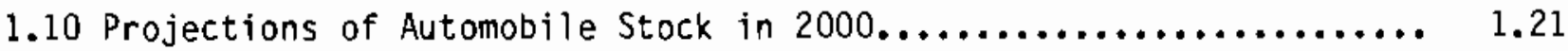

1.11 Summary of Projected Automobile Ownership, Use, and Energy Demand...................................... 1.22 


\subsection{LIGHTWEIGHT MATERIALS FOR GROUND TRANSPORTATION}

To determine the impact of lightweight materials on ground transportation, one must first establish the breakdown of materials composition of the various transportation modes. This volume concentrates on characterizing the materials composition of the automobile transportation system and establishing the potential for energy conservation by using lightweight materials; much less is known, and therefore reported, on the other transportation modes.

Until 1977, the U.S. passenger car models of fered by competing manufacturers had evolved into similar classes of vehicles in terms of size, performance, and component characteristics. Competition that centered on performance, comfort, convenience, and luxury led to gradual, incremental changes in size and weight. After the 1973 oil embargo, the escalation of fuel prices made fuel economy a significant competitive factor. By 1977, overall downsizing of vehicles began in earnest as a means to reduce weight and, thereby, increase fuel economy. The trend towards vehicle weight reduction should continue as a result of regulations on fuel economy, emissions, noise, and safety.

of the energy released by the combustion of the fuel-air mixture in an automotive Otto cycle gasoline engine, only $25 \%$ is available at the engine crankshaft and is useful in the operation of the vehicle (see Section 1.2). The distribution of this available energy [brake horsepower (bhp)] in a typical automobile for the EPA composite driving cycle (JPL 1975) is shown in Figure 1.1. The energy uses that are directly proportional to weight are the tire rolling friction $(24.7 \%)$ and the power to accelerate the vehicle. The power required to accelerate the vehicle is directly proportional to the kinetic energy dissipated at the brakes $(12.6 \%)$ by virtue of the first 1 aw of thermodynamics. The energy uses influenced by the engine size (horsepower) are fuel consumed while coasting and idling (16.3\%) and transmission losses $(12.1 \%)$. Since the required level of performance is attained by making the engine horsepower roughly proportional to the weight, transmission losses and coasting/idling fuel consumption are indirectly but significantly influenced by weight. Aerodynamic drag area varies, but not proportionately with weight. On the average, $65.7 \%$ of the available bhp is associated with the weight of the car. Therefore, fuel economy can be improved by reducing vehicle weight. 


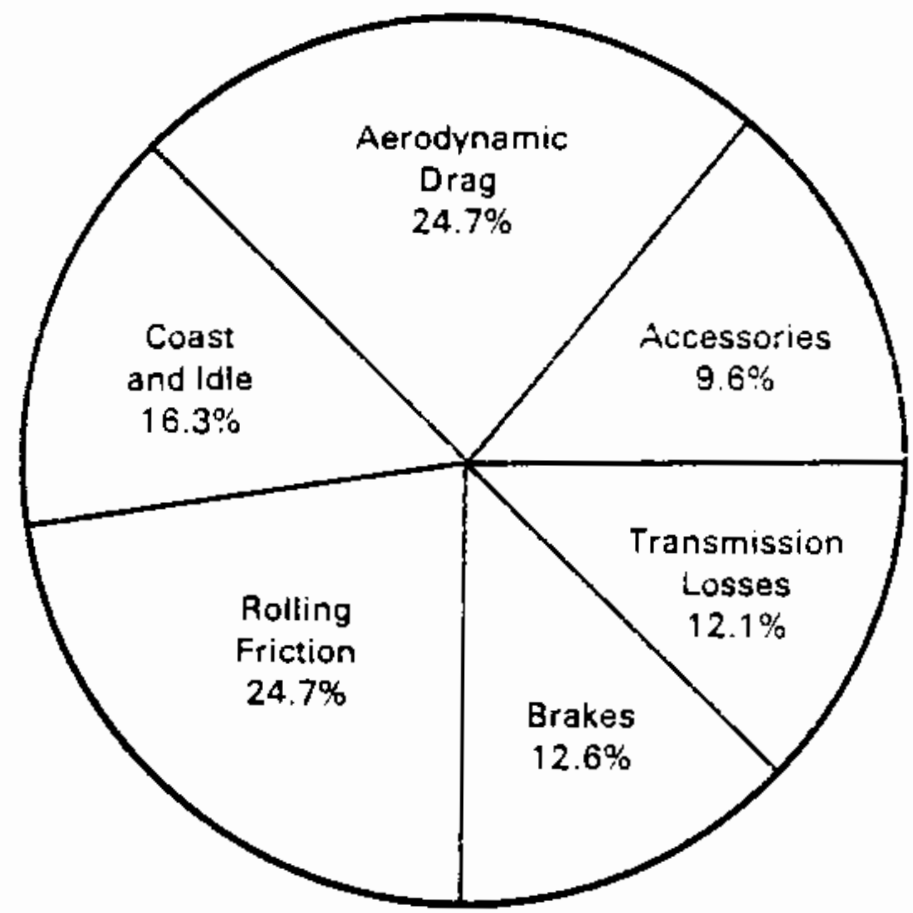

FIGURE 1.1. Typical Automobile Energy Requirements for the EPA Specified Composite Driving Car (JPL 1975)

The dominant strategy adopted by the automobile industry in improving fuel economy has been to reduce vehicle weight through downsizing and materials substitution. Downsizing has been accomplished by packaging the main vehicle components more closely, reducing interior waste space, reducing the width, shortening the trunk overhang, and reducing styling-induced waste space forward of the firewall. In the smallest car categories, the most practical way of packaging power train components was the front engine, front-wheel-drive layout. Weight reduction via downsizing becomes more difficult as the car becomes sinaller and the design of the components approaches the optimum. Further reduction in vehicle weight is then achieved through materials substitution.

Materials substitution is a slower process than simple size changes. The time required to phase new materials into a production automobile is shown in Figure 1.2 (Paul 1979). Although there appear to be no major technical problems with downsizing, there are technical limitations on materials substitution. These limitations are associated with the performance requirements for the part using the substitute material, with feasibility of fabrication, 


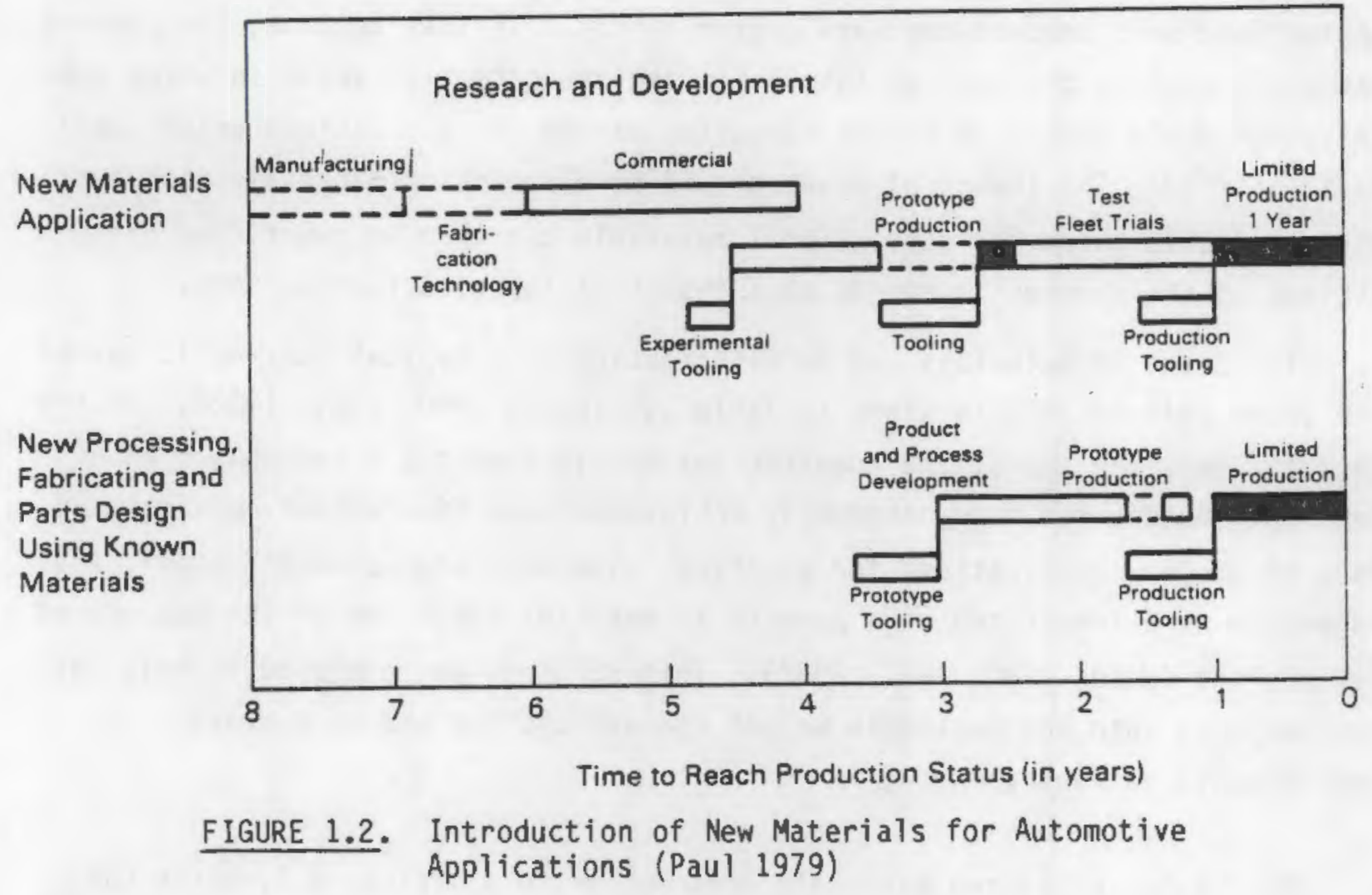

and with assembly of the part into the automobile at a production rate. Specific components, as well as the entire vehicle structure, must meet individual component and overall system design criteria for rigidity, strength, and dynamic response; lightweight materials can be substituted only when the capabilities of the components made of these materials can meet or exceed the required criteria. Substitution concepts sometimes entail redesign of associated parts as well as principal parts. Component designs and fabrication procedures that are compatible with other manufacturing processes used in automobile production must be developed. Materials substitution must also take into consideration other factors such as cost, appearance, and durability.

\subsection{STATUS OF MATERIALS USE IN THE AUTOMOBILE}

Data on the materials composition of automobiles in the different weight classes are not readily available. However, data on the typical or average U.S. car (fleet average weight for a given production year) are reported (Wards 1980, 1981, 1982; MVMA 1982). This makes the typical automobile a relevant and 
appropriate unit process hardware system (UPHS). In this section, the current materials used in the typical automobile and the potential areas in which substitution would result in direct reduction of the overall vehicle weight will be identified. The impact of research and development of materials that can be directly substituted for conventional materials can then be quantified by estimating the savings in energy as a result of improved fuel economy.

The trend in materials use or distribution in a typical U.S.-built car of the years 1976 to 1982 is shown in Table 1.1 (Wards 1980, 1981, 1982). In the last six or seven years, the domestic automobile industry's new models have been introduced with some noteworthy achievements in lightweight applications. Many of the new applications for plastics, aluminum, high-strength steel, and magnesium were instituted at a penalty in material costs and in the expense of new tooling (Wards 1980, 1981, 1982). This strategy was employed to help put the new cars into the desirable weight classifications and to achieve improvements in fuel economy.

TABLE 1.1. Estimated Materials Consumption in a Typical U.S.-Built Car (pounds) (Wards 1980, 1981, 1982)

\begin{tabular}{|c|c|c|c|c|c|c|}
\hline Material & 1982 & 1981 & 1980 & 1979 & 1978 & 1976 \\
\hline High-strength steel & 203.0 & 190.0 & 175.0 & 150.0 & 133.0 & 120.0 \\
\hline Aluminum & 134.0 & 130.0 & 130.0 & 119.0 & 112.5 & 85.5 \\
\hline Plastics & 200.0 & 198.0 & 195.0 & 185.0 & 180.0 & 162.5 \\
\hline Glass & 84.0 & 83.0 & 83.5 & 85.0 & 86.5 & 87.5 \\
\hline Copper & 28.0 & 27.5 & 28.0 & 28.5 & 29.0 & 32.0 \\
\hline Zinc die castings & 15.5 & 17.0 & 20.0 & 25.0 & 31.0 & 44.0 \\
\hline Rubber & 135.0 & 133.0 & 131.0 & 137.5 & 146.5 & 153.0 \\
\hline Lead & 23.5 & 22.5 & 23.0 & 24.0 & 25.0 & 25.0 \\
\hline Stainless steel & 27.0 & 26.5 & 27.5 & 27.0 & 26.0 & 28.0 \\
\hline Iron & 461.0 & 470.0 & 484.0 & 498.0 & 512.0 & 562.0 \\
\hline Plain carbon steel & 1469.0 & 1602.0 & 1737.0 & 1846.0 & 1915.0 & 2075.0 \\
\hline Fluids, lubricants & 179.0 & 175.0 & 178.0 & 189.0 & 198.0 & 190.0 \\
\hline $\begin{array}{l}\text { Others (alloy steel, } \\
\text { cloth, cardboard, etc) }\end{array}$ & 155.0 & 153.0 & 151.0 & 162.0 & 175.0 & 196.0 \\
\hline Total & 3114.0 & 3228.0 & 3363.0 & 3475.0 & 3569.5 & 3760.5 \\
\hline
\end{tabular}


The broad categories of primary materials used in the manufacture of cars, together with their relative contribution in an average 1975 vehicle, are shown in Table 1.2 (Energy Resources Council 1976). In the Federal Task Force Report (Energy Resource Council 1976), which seeks to establish the motor vehicle goals beyond 1980, a baseline motor vehicle weight configuration was established through an analysis of the weight composition of a number of 1975/1976 and prior model year vehicles. This analysis showed that the proportion of each material used has remained substantially the same since 1955 . To set the goals beyond 1980, weight-conscious and innovative structure goals were defined for comparison with the baseline weight configuration. The weight-conscious configuration is achieved through downsizing without sacrificing interior space, while the innovative structure is achieved by increasing use of plastic/ aluminum from $10 \%$ to $15 \%$. The weight-conscious and the innovative automobile configurations are compared with the baseline configuration in Figure 1.3 and Table 1.3. There was no distinction between the relative material content of the weight-conscious vehicle and the 1975 baseline configurations. However, the relative contribution of steel is expected to decrease to $57 \%$ in the case of the innovative vehicle.

TABLE 1.2. Materials in the 1975 Automobile (Energy Resources Council 1976)

\begin{tabular}{l} 
Material \\
\hline Iron Castings: \\
Gray \\
Malleable and nodular \\
Steel: \\
Carbon \\
Galvanized \\
Aluminized \\
Alloy \\
Stainless \\
Other: \\
Aluminum \\
Zinc \\
Copper \\
Lead \\
Glass \\
Rubber \\
Plastics \\
Miscellaneous materials
\end{tabular}

Percent of Average Auto Weight

$12.0-13.0$
$4.0-5.0$

$53.0-55.0$

$1.5-2.0$

$0.8-1.0$

$2.5-3.0$

$0.4-0.5$

$2.2-2.5$

$0.8-1.0$

$0.5-0.7$

$0.7-0.9$

$2.0-2.5$

$4.5-5.3$

$3.0-3.7$

$7.9-9.5$ 


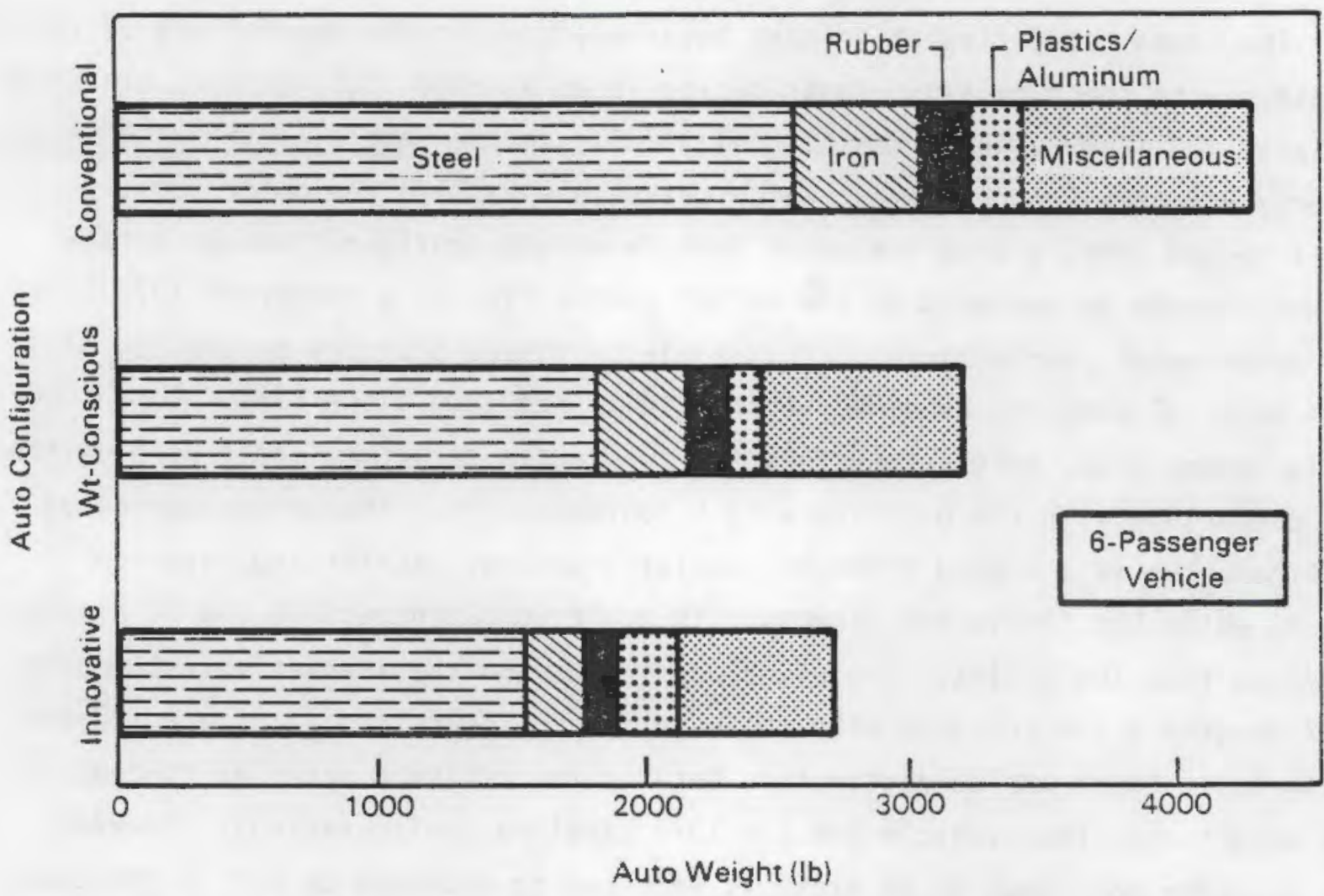

FIGURE 1.3. Average Motor Vehicle Material Composition by Weight (Energy Resources Council 1976)

TABLE 1.3. Comparison of Baseline and Goal Material Content in Motor Vehicles (Energy Resources Council 1976)

\begin{tabular}{lcccc} 
Material & Current Vehicle & & $\begin{array}{c}\text { Weight } \\
\text { Conscious Vehicle }\end{array}$ & Innovative Vehicle \\
\cline { 5 - 5 } Steel & $60.0 \%$ & & $60.0 \%$ & $57.0 \%$ \\
Iron & $13.0 \%$ & $13.0 \%$ & $10.0 \%$ \\
Rubber & $3.8 \%$ & $3.8 \%$ & $3.8 \%(\mathrm{a})$ \\
Plastics & $2.7 \%$ & $2.7 \%$ & $2.7 \%(\mathrm{a})$ \\
Aluminum & $2.4 \%$ & $2.4 \%$ & $8.3 \%(\mathrm{a})$ \\
Glass & $2.3 \%$ & $2.3 \%$ & $2.3 \%$ \\
Other & $15.8 \%$ & $15.8 \%$ & $15.9 \%$ \\
Total & $100.0 \%$ & $100.0 \%$ & $100.0 \%$
\end{tabular}

(a) The total aluminum/plastic material content of an innovative motor vehicle structure is estimated to be about $11 \%$. The breakdown between plastic and aluminum will be strongly sensitive to cost and availability of material. 
Table 1.1 shows that the contribution of steel has dropped from $59 \%$ in 1976 , to $58 \%$ in 1980 , and $55 \%$ in 1982 . The contribution of plastic/aluminum in the $1982 \mathrm{car}$ is approximately 11\%. The $1982 \mathrm{car}$ is therefore already close to the conceptual innovative configuration in the relative contributions of steel and plastic/aluminum, and is comparable to the weight-conscious configuration in total weight.

The candidate substitute automotive materials, their potential for direct weight reduction, and the relative material cost (DOT 1979) are given in Table 1.4. The table summarizes the ranges in percent vehicle weight reduction achieved through application of the various materials. The weight reduction potential was estimated in relation to materials (e.g., steel, cast iron, or

glass) used in the 1978 model year car. High-strength, low-alloy steels have a potential to reduce vehicle weight by as much as $15 \%$ to $30 \%$ at approximately the same cost as the original material.

Research areas for the alternative materials (DOT 1979) that will accelerate the substitution are given in Table 1.5.

\subsection{EFFICIENCY ESTIMATE}

The efficiency with which the energy content of the liquid fuel is converted to the motive power that propels an automobile over distance is illustrated in Figure 1.4 for a passenger car driven in a specified EPA cycle. At Level 1 the energy content of the fuel, released through the thermo-chemical process of combustion in a thermodynamic 0tto cycle, is not all available to push against the pistons. Twenty-nine percent (29\%) is not available by virtue of the second law of thermodynamics and must be rejected to a heat sink (in this case, to ambient air via cylinder cooling and radiator fan heat rejection); $33 \%$ of the energy contained in combusted and unburned fuel goes out with the gases exhausted from the cylinder, the 0tto cycle being an open-cycle power system.

At the second level of conversion (Level 2), the $38 \%$ of initial fuel energy applied to pushing on pistons is shown to be distributed as follows: $3 \%$ is dissipated as the piston rings rub against the cylinder walls; $6 \%$ is 
TABLE 1.4. Candidate Alternative Automotive Materials (in percent) (DOT 1979)

Material

Wrought Metal

Low-carbon steel (LCS)

Dent-resistant steels

High-strength/low-alloy

steel

U1tra-high-strength steel

Aluminum (A1)

Metal Castings

Grey iron

Al die casting

Al permanent mold casting

Zinc die casting

Magnesium die casting

Plastics (relative to LCS)

Unidirectional fiberglass reinforced polyester or epoxy resin

Sheet molding compound, random fiberglass reinforced polyester resin

Unidirectional graphite fiber reinforced epoxy resin (hybrid reinforcement with fiberglass, where possible)

Continuous fiberglass reinforced nylon "STX"

hot stampable sheet
Weight Reduction Potential (a)
Relative Material

Cost Per Part Based on Current Technology (b)
10 to $\overline{20}$
1
15 to 30
0.8 to 1
40 to 50
0.9 to 1.1
50 to 60
0.7 to 0.8
1 to 3

50 to $\overline{60}$

50 to 60

10 to 40

75

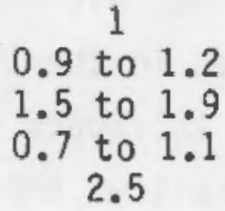

50

2

35 to 50

1.15

Transparent materials

Glass

Polycarbonate

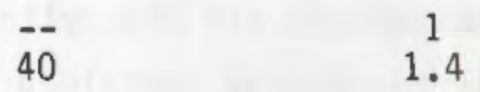

(a) with respect to materials such as steel, cast iron, or glass used in the 1978 model year car

(b) material cost only, not including direct labor or variable manufacturing burden

(c) based on a projected cost for graphite of $\$ 6 / 1 \mathrm{~b}$, present cost $\$ 20 / 1 \mathrm{~b}$

(d) project values. 
TABLE 1.5. Materials Technology - Illustrative Research Areas (DOT 1979)

Steel

Improved materials properties

Advanced high-strength, multiphase, ferrous-based alloys

Improved materials/processes for corrosion prevention

Improved manufacturability

Forming research and development

Joining

Aluminum

Lower cost of raw materials (including new refining processes)

Improved materials properties

Corrosion resistance

Fatigue resistance

Stiffness

Improved manufacturability to reduce cost

Formability

Joining

Finishing

Data and manufacturing experience to increase designer's confidence

Plastics and Composites

Lower cost raw materials

Materials based on renewable feed stocks

Lower cost reinforcing graphite fibers

Improved materials properties

Develop materials with overall improvement in properties

Develop high-temperature resins

Develop stronger and stiffer fibers

Develop/design optimized hybrid composites

Analyze resin/fiber interface

Improved manufacturability to reduce cost

High-speed, short-cure cycle molding processes

Thermoplastic preforms

Joining 


\section{TABLE 1.5. (contd)}

Plastics and Composites (Continued)

Fabricate larger parts

Finishing

Non-destructive testing (NDT)

Increased designer confidence

Fatigue properties

Reliability and durability of composite parts

Crashworthiness

Engineering properties and design criteria

Environmental impacts

Recycling

Non-toxic substance emitting materials

Health hazards due to fibrous reinforcements

Foam-Filled and Multimaterial Composities and Other Materials

Foam core structural components

Low-cost manufacturing process for magnesium

Metal matrix composities

Optimized multimaterial systems

Improved Glazing

Elimination of lacerations upon impact (windshields, side and rear glazing)

Improved strength for structural purpose and weight reduction

expended in inducting the air-fuel mixture and in exhausting the products of combustion; $4.5 \%$ is dissipated as other friction losses such as crank, pin, and connecting rod friction. Only. the remainder, $25 \%$, is available at the crankshaft for delivery to the wheels to move the automobile and its load. This is the bhp shown in Figure 1.4.

Not all the power (energy) available at the crankshaft is available to propel the automobile. Two percent $(2 \%)$ is necessary to operate such components as the alternator, air pump, cooling fan and water pump, and $0.5 \%$ 


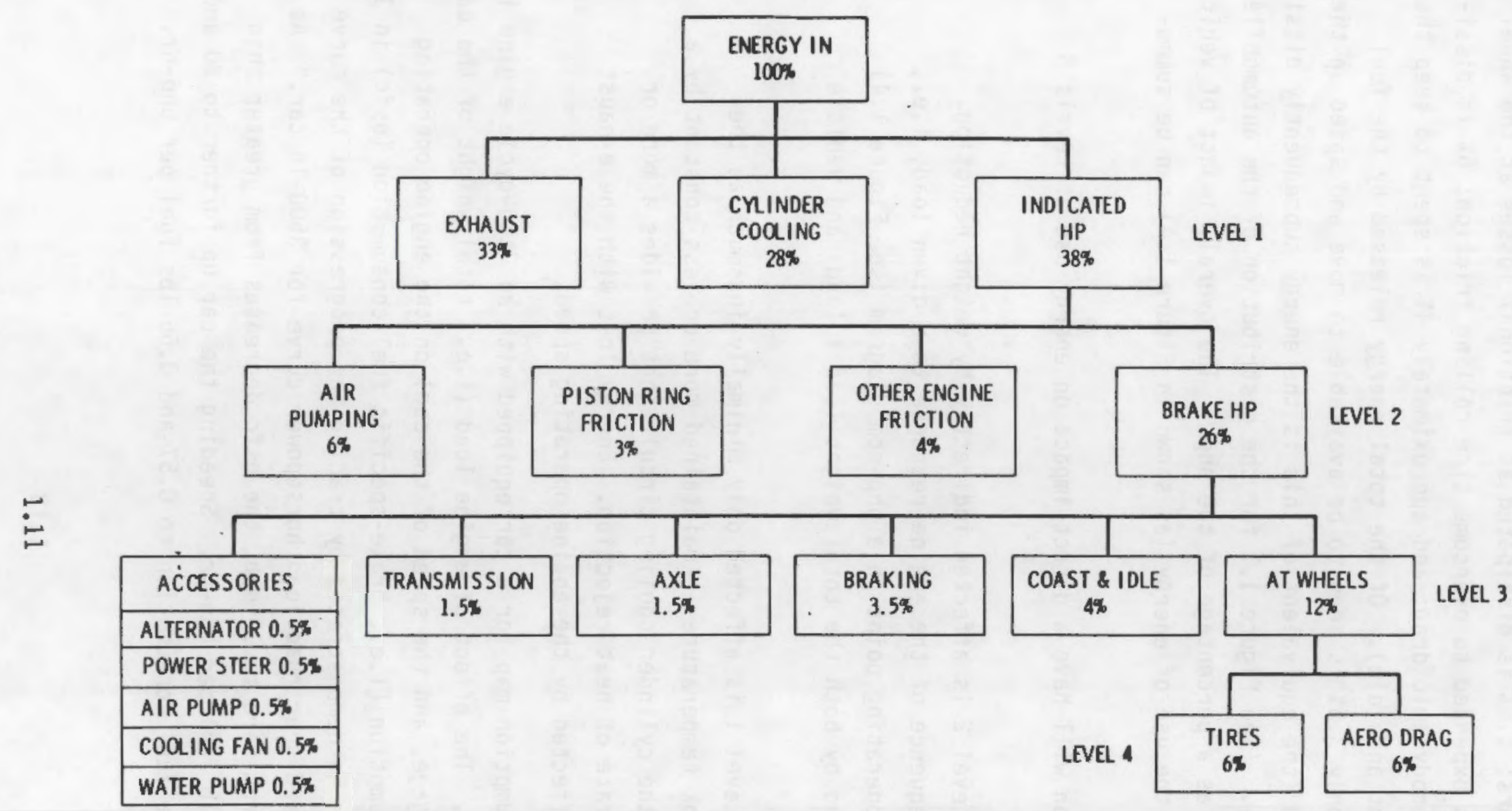

FIGURE 1.4. Energy Use in Passenger Car During EPA Cycle (Hopp 1981) 
for power steering, if used; $1.5 \%$ is dissipated as losses at the transmission and differential gears; $1.5 \%$ is dissipated as frictional losses at the wheel axle bearings; $6 \%$ is expended to overcome tire rolling friction; $6 \%$ is dissipated to overcome aerodynamic drag; and approximately $4 \%$ is spent to keep the engine running (coast and idle). Of the total energy released by the fuel during combustion, only $3.5 \%$ is seen to be available to move and speed up the vehicle and its load (the equivalent of this is the energy subsequently dissipated at the brakes). (See Figure 1.1 for the distribution of the automobile energy requirements as a percentage of the bhp.) The overall impact of vehicle weight reduction on the use of energy (as shown in Figure 1.4) can be summarized as follows:

o Weight reduction will have a direct impact on energy use at Levels 3 and 4.

- Energy use at Level 2 is affected indirectly by weight reduction. This is a consequence of the engine response to a given load, i.e., on the engine operating point on a bhp-rpm diagram (see Figure 1.4) that is affected by both the total weight (car + load) and vehicle speed (mph).

- Energy use at Level 1 is affected only minimally inasmuch as the engine heat sink temperature is maintained more or less constant by a thermostat in the cylinder cooling circuit that provides a more or less constant rate of heat rejection. Energy lost with the exhaust gases can be affected by the engine operating speed.

A typical fuel consumption map for a car equipped with an 0tto-cycle engine is shown in Figure 1.5. The effect of engine load (i.e., total weight of the car, passengers, and baggage, and the speed of the car) on the engine operating point and fuel consumption [i.e., brake-specific fuel consumption (bsfc) in lb fuel per bhp-hr] can be demonstrated by tracing the progression of the curve labeled "typical fixed-gear road load horsepower curve for 3500-1b car." As the car speeds up from zero to $70 \mathrm{mph}$, the bsfc decreases from greater than 0.80 to about $0.55 \mathrm{lb}$ fuel per bhp-hr. Speeding the car up further to 80 and $90 \mathrm{mph}$ increases the fuel consumption to 0.57 and 0.66 lbs fuel per bhp-hr. 


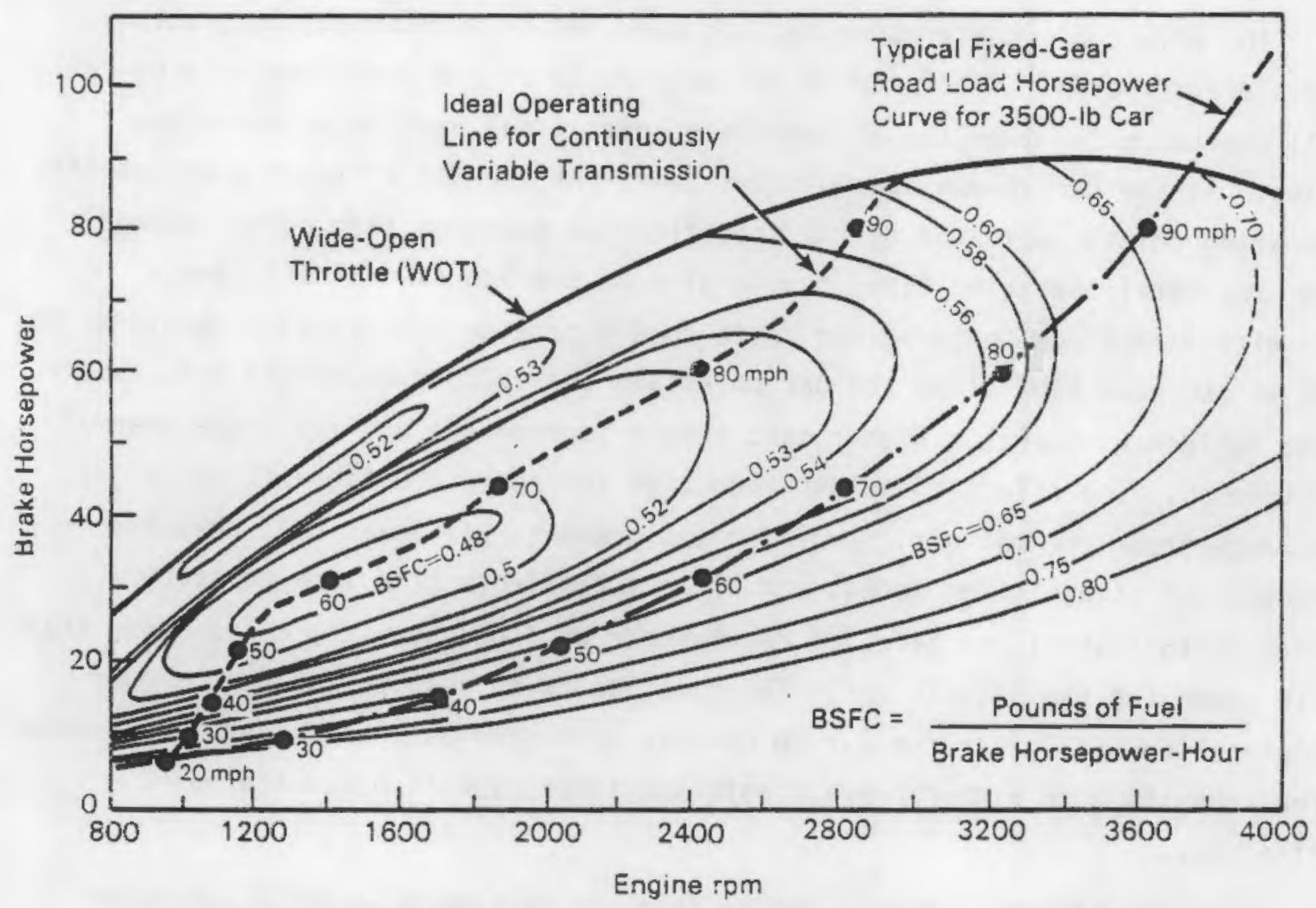

FIGURE 1.5. Typical Fuel Consumption Map for Otto Cycle Engine (JPL 1975)

The brake thermal efficiency, $n_{b}$, is computed from the bsfc using the following equation:

$$
n_{b}=2545 /\left(\text { bsfc } \cdot n_{f}\right)
$$

where $h_{f}=$ heating value of the fuel, Btu/l $b_{m}$ of fuel

Using the example of Figure 1.5, a 3500-1b car running at $25 \mathrm{mph}$ in the city has the engine operating at a bsfc of $0.80 \mathrm{lb}$ gasoline per bhp-hr, a thermal efficiency of $16.8 \%$ [using Equation (1)] and a heating value of $18,900 \mathrm{Btu} / 1 \mathrm{~b}_{\mathrm{m}}$ of gasoline. Highway driving at $55 \mathrm{mph}$ results in a bsfc of 0.59 1b gasoline per bhp-hr with the corresponding brake thermal efficiency of $22.8 \%$. 
The effect of acceleration has not been factored in this illustration. The average thermal efficiency of the automobile over a specified driving cycle will depend on the time the automobile spends at one particular operating point. As the car speeds up and slows down, the thermal efficiency at specific operating points, weighted by the specific time spent at that point, summed over the total operating time, should give an average thermal efficiency. A car with an optimum hp-to-weight ratio should provide satisfactory acceleration and at the same time allow the car to attain the optimum operating bsfc sooner. Less residence time at a higher bsfc should improve the overall brake thermal efficiency. The effect of weight reduction for an automobile will be to increase break thermal efficiency for two reasons: 1) lower bsfc than the 3500-ib car at any given speed, and 2) less residence time (due to faster acceleration) at higher bsfc. A heavier car will operate in a curve lower than that shown for the 3500-ib car. The combination of heavier load and slower acceleration will cause the car to operate at higher bsfc with longer residence time, resulting in higher overall bsfc and lower overall brake thermal efficiency.

When considering a bigger engine (i.e., 8 cylinders versus 6 cylinders versus 4 cylinders), one should bear in mind that different fuel consumption maps should be used. The increase in engine output is in discrete steps and the hp-to-weight ratio is changed. To move the same load, the bigger engine will operate at the lower rpm range for the same driving cycle and will be generating the same overall power output at a higher bsfc. Thus, it is expected that an automobile equipped with an engine for a suitable hp-to-weight ratio (approximately $0.03 \mathrm{hp}$ per lb weight) will operate at a higher overall brake thermal efficiency than a similar one equipped with the next available higher hp engine with more cylinders.

Fuel economy is of vital concern to the automotive industry because of the Energy Policy and Conservation Act passed into 1 aw on December 22, 1975. This act mandated a production-weighted Corporate Average Fuel Economy (CAFE) for passenger automobiles to increase from $18 \mathrm{mpg}$ in 1978 to $27.5 \mathrm{mpg}$ in 1985 . The CAFE standards can be met either by using more efficient power plants or by using lighter weight automobiles. Alternative power plants improve the fuel 
economy by providing higher efficiencies of energy conversion; lightweight materials improve the fuel economy by improving the efficiency of energy utilization. As illustrated in the previous paragraphs, the engine is made to operate at the conditions where the engine output meets the requirements of the load (i.e., total weight to be moved and the speed). In considering the impact of using lightweight materials in ground transportation, it should be assumed that automobile systems are similarly equipped, powerwise, and improvements in energy utilization therefore come as improvements in fuel economy, measured in mpg.

The functional relationship between fuel economy, vehicle test weight, and rated engine horsepower is given by the following equation (Energy Resources Council 1976):

$$
F_{e}=A(W)^{-a}(H p / W)^{-b}
$$

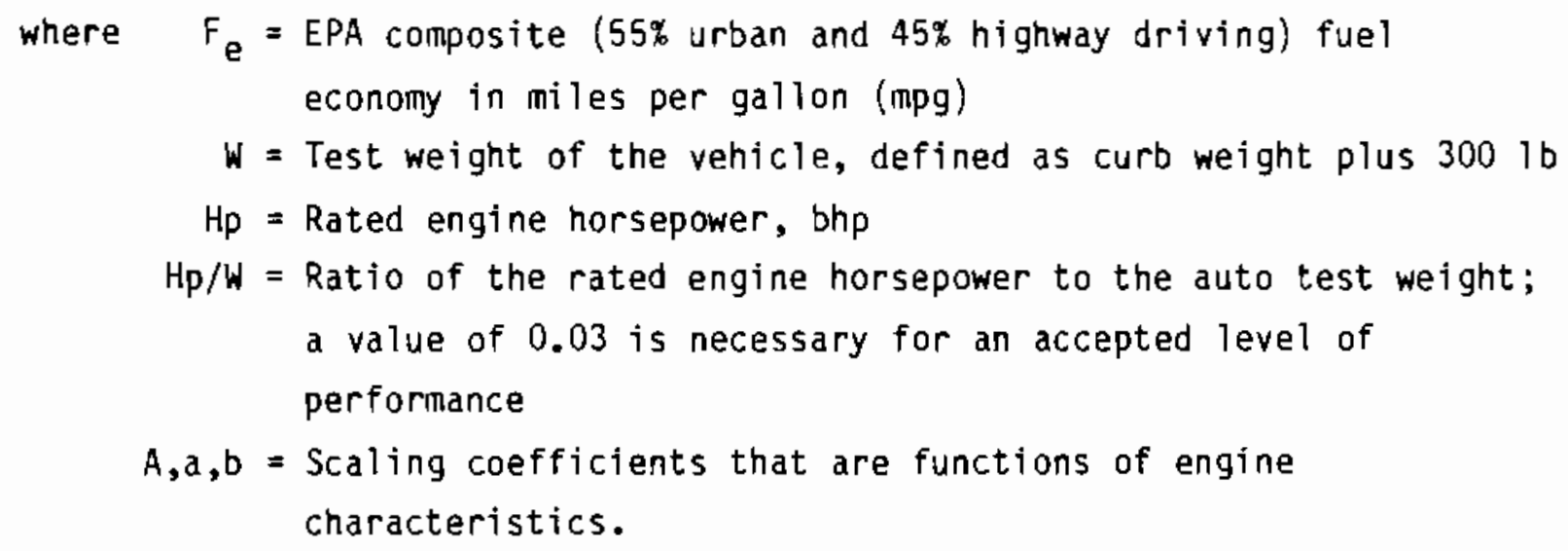

For a vehicle equipped with a standard gasoline engine, the scaling coefficients derived through a regression analysis of actual 1975/1976 EPA fueleconomy data are (Energy Resources Council 1976):

$$
A=6060 ; \quad a=0.88 ; \quad b=0.40
$$

For vehicles with diesel engines, the values of the scaling coefficients determined from avaitable data of dynamometer tests of diesel engines are (Energy Resources Council 1976): 


$$
A=2370 ; \quad a=0.69 ; \quad b=0.35
$$

The vehicle fuel consumption $F_{c}$ in gallons per mile can be derived from Equation (2), and is given by

$$
F_{c}=(W)^{a}\left(H_{p} / W\right)^{b} / A
$$

The change in fuel consumption per unit change in vehicle test weight is given by

$$
\mathrm{dF}_{c} / \mathrm{dW}=(\mathrm{a} / \mathrm{A})(\mathrm{W})^{\mathrm{a}-1}(\mathrm{Hp} / \mathrm{w})^{\mathrm{b}}
$$

for the case where $(H p / W)$ is maintained constant (i.e., level of performance is maintained); or

$$
\mathrm{dF}_{c} / \mathrm{dW}=(\mathrm{a}-\mathrm{b})(\mathrm{W})^{\mathrm{a}-\mathrm{b}-1}(\mathrm{Hp})^{\mathrm{b}} / \mathrm{A}
$$

for the case where the engine is not changed, and therefore the Hp is maintained constant.

Using Equation (4) a 3,000-1b test weight vehicle equipped with a gasoline engine such that $\mathrm{Hp} / \mathrm{W}=0.030 \mathrm{hp}$ per lb should expect a fuel consumption change of approximately $1.4 \times 10^{-5} \mathrm{gal} / \mathrm{lb}-\mathrm{mile}$. On the other hand, the same vehicle equipped with a diesel engine with $\mathrm{Hp} / \mathrm{W}=0.030 \mathrm{hp}$ per $1 \mathrm{~b}$ will have an estimated fuel consumption change of $7.1 \times 10^{-6}$ gal/lb-mile.

Because of weight propagation effects, care should be taken in estimating direct weight savings through substitution of lightweight materials for steel. The direct removal of 1 lb of original material from the automobile structure can result in a reduction of greater than 1 ib in the curb weight of the automobile because the requirement for suspension and support structure will also be reduced. The reduction in required engine power and, consequently, engine weight, will also result in decreased curb weight. Estimates of the weight propagation factor range from 1.4 to 2.6 (ARGOS 1978). A car manufacturer 
recently achieved a 0.76 secondary weight reduction ratio (corresponding to a weight propagation factor of 1.76 ) in an advanced concept lightweight vehicle (Cummings-Saxon 1981).

\subsection{CAPITAL STOCK INFORMATION}

\subsubsection{Capital Stock Information, 1980}

Oak Ridge (1981) estimates that there were 104,564,000 automobiles in use in 1980. The breakdown of automobiles among the six categories of vehicles is shown in Table 1.6 .

TABLE 1.6. Automobile Stock in 1980 by Size Category

\begin{tabular}{lrr} 
Category & Number & $\begin{array}{r}\text { Percent of } \\
\text { Total }\end{array}$ \\
\cline { 3 - 4 } Two seater & $1,687,000$ & $1.6 \%$ \\
Minicompact & $7,010,000$ & $6.7 \%$ \\
Subcompact & $20,042,000$ & $19.2 \%$ \\
Compact & $15,772,000$ & $15.1 \%$ \\
Midsize & $25,471,000$ & $24.4 \%$ \\
Large & $34,582,000$ & $33.1 \%$
\end{tabular}

Information describing the sales of domestic and imported automobiles in 1980 is shown in Table 1.7. The table shows that subcompact cars had the largest share of the market at $38.0 \%$, with midsize following at $33.7 \%$, and large cars third at $13.4 \%$. This is a notable market shift from 1978 when midsize had the largest share of the market at $31.6 \%$, followed by large and subcompact cars, which had $20.0 \%$ and $19.9 \%$ of the market, respectively. A comparison of the market shift between 1978 and 1980 is provided in Table 1.8.

Information on the survival and scrappage rates of automobiles is illustrated in Figure 1.6 and Table 1.9. The survival probability curve for automobiles as a function of their age is shown in Figure 1.6. One can see from the figure that the "half-life" for automobiles is approximately 10 years. Points on the curve are tabulated in Table 1.9, which also presents information on scrappage rates, the number of vehicles in operation, and the percent of vehicle-miles traveled (by age group). 
TABLE 1.7. Motor Vehicles in Use, Sales and New Registration in the United States, 1980 (Oak Ridge 1981)

\begin{tabular}{|c|c|c|c|c|c|c|c|}
\hline & \multirow{3}{*}{$\begin{array}{l}\text { Motor Vehicles } \\
\text { in Use as of } \\
\text { July } 1,1990 \\
\text { (in thausands) }\end{array}$} & \multicolumn{6}{|c|}{ Sales } \\
\hline & & \multicolumn{2}{|c|}{ Domestic } & \multicolumn{2}{|c|}{ Imported (a) } & \multicolumn{2}{|c|}{ Total } \\
\hline & & (in thousands) & $\begin{array}{l}\text { Percentage } \\
\text { Domestic }\end{array}$ & (in thousands) & $\begin{array}{l}\text { Percentage } \\
\text { Import }\end{array}$ & (in thousands) & $\begin{array}{l}\text { Percentage } \\
\text { by Class }\end{array}$ \\
\hline $\begin{array}{l}\text { Autanobiles } \\
\text { Two seater } \\
\text { Minicompact } \\
\text { Subcompact } \\
\text { Compact } \\
\text { Midsize } \\
\text { Large }\end{array}$ & $\begin{array}{r}104,564 \\
1,687 \\
7,010 \\
20,042 \\
15,772 \\
25,471 \\
34,582\end{array}$ & $\begin{array}{c}6,369(\mathrm{~b}) \\
37 \\
169 \\
1,444 \\
533 \\
2,993 \\
1,193\end{array}$ & $\begin{array}{r}100.0 \\
0.6 \\
2.6 \\
22.7 \\
8.4 \\
47.0 \\
18.7\end{array}$ & $\begin{array}{r}2,527 \\
179 \\
234 \\
1,936 \\
175 \\
3 \\
0\end{array}$ & $\begin{array}{r}100.0 \\
7.1 \\
9.3 \\
76.6 \\
6.9 \\
0.1 \\
0.0\end{array}$ & $\begin{array}{r}8,896 \\
216 \\
403 \\
3,380 \\
708 \\
2,996 \\
1,193\end{array}$ & $\begin{array}{r}100.0 \\
2.4 \\
4.5 \\
38.0 \\
8.0 \\
33.7 \\
13.4\end{array}$ \\
\hline $\begin{array}{l}\text { Fleet (4+) } \\
\text { Personal }\end{array}$ & $\begin{array}{l}10,433^{(c)} \\
94,131\end{array}$ & & & & & & \\
\hline Wtorcycles & 7,400 & 130 & 10.4 & 1,120 & 89.6 & 1,250 & 100.0 \\
\hline Mopeds & 1,000 & (d) & & (d) & & 210 & 100.0 \\
\hline Recreational vehicles & 6,000 & $308(\mathrm{e})$ & 100.0 & 0 & 0.0 & 308 & 100.0 \\
\hline $\begin{array}{l}\text { Trudss }(f) \\
\text { Light } \\
\text { Medium } \\
\text { Light-Heavy/Heavy-Heavy }\end{array}$ & $\begin{array}{r}35,268 \\
30,119 \\
2,116 \\
\quad 1,093\end{array}$ & $\begin{array}{r}2,035 \\
1,765 \\
6 \\
89\end{array}$ & $\begin{array}{r}100.0 \\
86.7 \\
0.3 \\
4.4\end{array}$ & $\begin{array}{l}485 \\
480 \\
5(g)\end{array}$ & $\begin{array}{c}100.0 \\
99.0 \\
1.0^{(9)}\end{array}$ & $\begin{array}{c}2,520 \\
2,245 \\
6 \\
269(9)\end{array}$ & $\begin{array}{c}100.0 \\
89.1 \\
0.2 \\
10.7(9)\end{array}$ \\
\hline
\end{tabular}

(a) Includes captive imports - Autombbiles: Arrow Chap, Sapporo, Colt, Challenger, Fiesta, and Opel. Trucks: Ohevrolet LWW, Ford Corrier, Plymouth Arrow, and Dodge D60.

(b) Total does not include sane 32,785 special purpose vehicles (AMC Eagle), which are classified with trucks.

(c) Includes federal governient vehicles.

(d) Not available.

(e) Shiprents only.

(f) Includes vans and special purpose vehicles; also AMC Eagle. Before MN 1980, passenger vans were included with autanobile sales data.

(g) Includes heavy-heavy. 
TABLE 1.8. Market Shift in Automobile Sales Between 1978 and 1980 (Oak Ridge 1981)

\begin{tabular}{|c|c|c|c|}
\hline \multirow[b]{2}{*}{ Category } & \multicolumn{3}{|c|}{$\begin{array}{c}\text { Market Share of Sales } \\
\text { (in percent) }\end{array}$} \\
\hline & 1978 & 1979 & 1980 \\
\hline Two seater & 1.2 & 0.9 & 2.4 \\
\hline Minicompact & 12.8 & 5.0 & 4.5 \\
\hline Subcompact & 19.9 & 33.1 & 38.0 \\
\hline Compact & 14.0 & 9.3 & 8.0 \\
\hline Mid Size & 31.6 & 37.5 & 33.7 \\
\hline Large & 20.8 & 19.5 & 13.4 \\
\hline
\end{tabular}

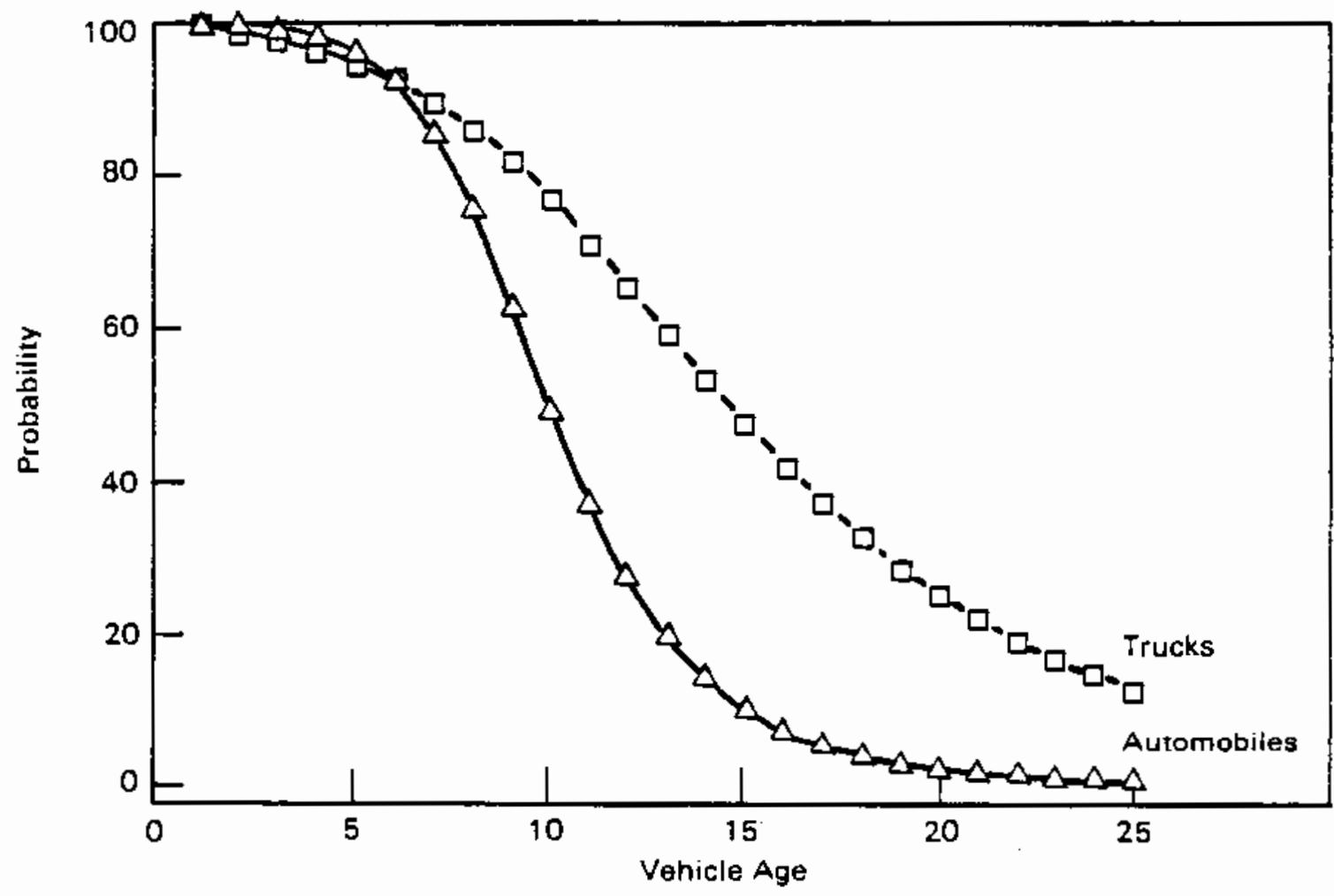

FIGURE 1.6. Survival Probability Curves for Automobiles and Light Trucks (Oak Ridge 1981) 
TABLE 1.9. Automobiles in Operation, Scrappage Rates, and Vehicle Travel by Age of Vehicle, 1980 (0ak Ridge 1981)

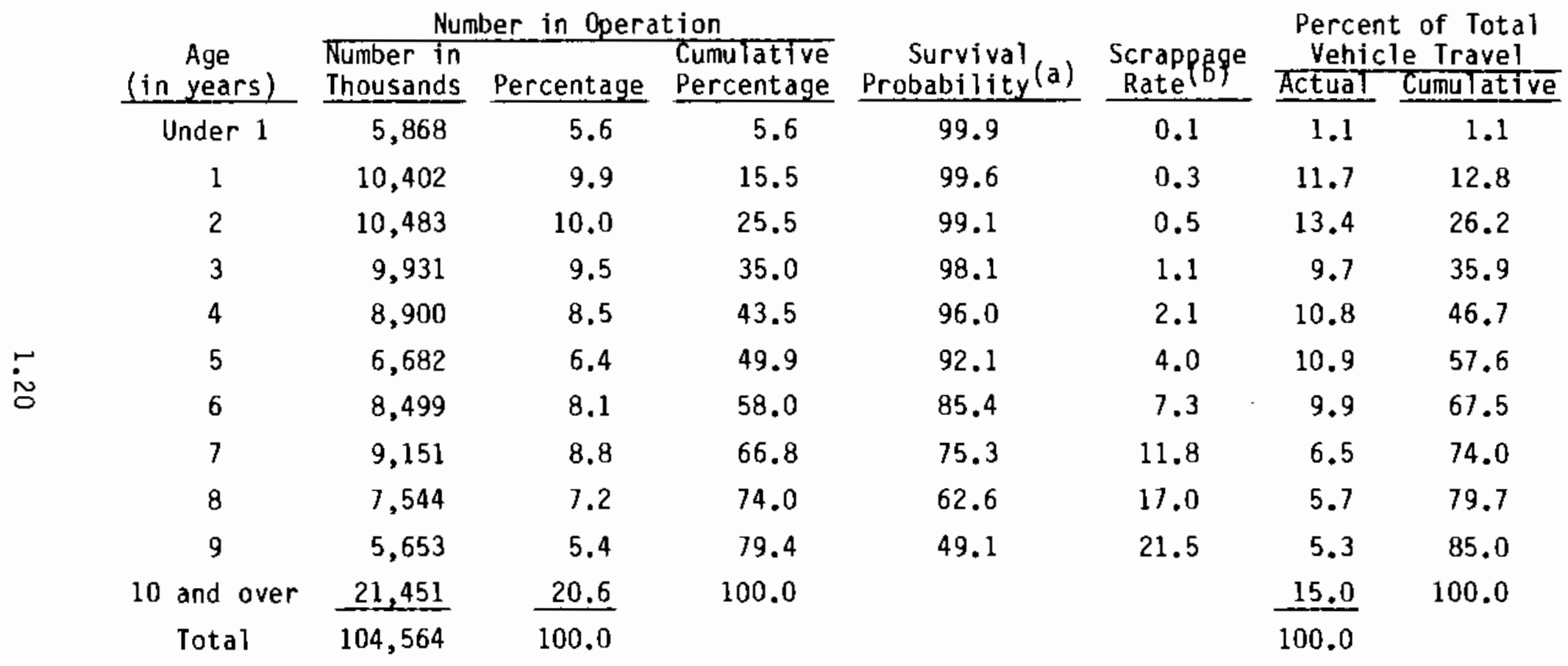

(a) The probability that a vehicle of a certain type in a given class will be "in use" (registered) in a given year.

(b) Percentage of vehicles of a certain type in a given age class that are retired from use (lacking registration) in a given year. 


\subsubsection{Capital Stock Information, 2000}

Since 1975, several models have been assembled to predict characteristics of the automobile stock and energy use up to the year 2000. Among the organizations performing the modeling were the Office of Technology Assessment, the Wharton School, Argonne National Laboratory, the DOE Office of Policy Planning and Analysis, the DOT Transportation Systems Center, Oak Ridge National Laboratory, Energy and Environmental Analysis, Inc., and 0ata Resources, Inc. Automobile stock in the year 2000 is projected to range from 131 million vehicles to 153 million vehicles with the values averaging around 140 million automobiles (see Table 1.10). The annual growth rates ranged from $1.2 \%$ to $1.9 \%$.

TABLE 1.10. Projections of Automobile Stock in 2000.

(Knorr and Millar 1979, Millar et al. 1982)

\begin{tabular}{lc}
\multicolumn{1}{c}{ Source of Projection } & $\begin{array}{c}\text { Estimated } \\
\left(\times 10^{6}\right)\end{array}$ \\
\cline { 1 - 1 } Office of Technology Assessment & 148 \\
Jet Propulsion Laboratory & 143 \\
Wharton School & 146 \\
Argonne National Laboratory & 136 \\
Office of Policy Planning and Analysis & 131 \\
Transportation Systems Center & 136 \\
Oak Ridge National Laboratory & 147 \\
Energy and Environmental Analysis, Inc. & 133 \\
Oata Resources, Inc. & 139
\end{tabular}

The office of Technology Assessment (OTA) developed two scenarios for the changes in 0tto and diesel engine use in automobiles. In Case $A$, the penetration of diesel engines was assumed to be $10 \%$ of new car sales in 1985 and $25 \%$ of new car sales in 2000. In Case $B$, the penetration of diesel engines was assumed to be $15 \%$ and $4 \mathrm{D} \%$ of new car sales for those same years. Combining these scenarios with an anticipated stock of 112 million autos in 1985 and $140 \mathrm{million}$ autos in 2000 (average values from the forecasts) yields the vehicle and energy-use information given in Table 1.11. In Case A, approximately 110 million of the automobiles would be powered by gasoline engines, and 
TABLE 1.11. Summary of Projected Automobile Ownership, Use, and Energy Demand

\begin{tabular}{|c|c|c|c|}
\hline & \multirow[b]{2}{*}{1980} & \multicolumn{2}{|c|}{2000} \\
\hline & & Case $\bar{A}$ & Case B \\
\hline Automobiles in operation (millions) & 104.5 & 140 & 140 \\
\hline $\begin{array}{l}\text { Aut omobile vehicle-miles traveled } \\
\text { (trillions) }\end{array}$ & 1.11 & 1.69 & 1.69 \\
\hline $\begin{array}{l}\text { Annual new car sales (millions) } \\
\text { Percent of Diesels }\end{array}$ & $\begin{array}{l}8.9 \\
5\end{array}$ & $\begin{array}{l}16 \\
25\end{array}$ & $\begin{array}{l}16 \\
40\end{array}$ \\
\hline $\begin{array}{l}\text { New car fuel economy (mpg) } \\
\text { EPA standard } \\
\text { Attained-actual driving }\end{array}$ & $\begin{array}{l}20.0 \\
20.4\end{array}$ & $\begin{array}{l}27.5 \\
25.0\end{array}$ & $\begin{array}{l}35.0 \\
29.8\end{array}$ \\
\hline $\begin{array}{l}\text { Fleet fuel economy (mpg) } \\
\text { Attained-actual driving }\end{array}$ & 14.3 & 24.6 & 28.0 \\
\hline $\begin{array}{l}\text { Annual fleet fuel consumption rate } \\
\text { (billions of gallons) } \\
\text { Gasoline } \\
\text { Diesel }\end{array}$ & $\begin{array}{r}79.4 \\
0.6 \\
\end{array}$ & $\begin{array}{l}56.4 \\
12.3 \\
\end{array}$ & $\begin{array}{l}42.9 \\
17.5 \\
\end{array}$ \\
\hline Total & 78.0 & 68.7 & 60.4 \\
\hline $\begin{array}{l}\text { Fleet fuel consumption } \\
\text { (millions of barrels per day) }\end{array}$ & 5.1 & 4.5 & 3.9 \\
\hline
\end{tabular}

(a) The EPA certification value for a particular car is the weighted average of performance in the EPA urban cycle (55\% weight) and rural cycle ( $45 \%$ weight).

in Case B the number would be approximately $96 \mathrm{million.} \mathrm{The} \mathrm{Case} \mathrm{A} \mathrm{proportions}$ are in fair agreement with Argonne's (Millar et al. 1982) estimate that $82.4 \%$ of the automobile stock in 2000 will be using Otto cycle engines, $17.4 \%$ diesel engines, and $0.2 \%$ other means of propulsion.

Factors that will affect the accuracy of the projections include the penetration of light-duty diesel engines, the price of gasoline, and shifting consumer preference between large and small automobiles.

\subsection{FUEL CONSUMPTION OEMAND}

\subsubsection{Fuel Consumption Demand, 1980}

Argonne (Millar et al. 1982) estimates that in 1980 automobiles consumed approximately 77.9 billion gallons of gasoline, or $9,740 \times 10^{12} \mathrm{Btu}$. By 
comparison, Oak Ridge (1981) estimates 79.4 billion gallons were consumed, or $9,930 \times 10^{12}$ Btu, accounting for $44.3 \%$ of the energy used in transportation. The Argonne values will be used here because they appear to be more consistent with other estimates of energy use.

The most recent data available on military automobile energy use indicate that $1.9 \times 10^{12}$ Btu (15.2 million gallons) of gasoline were used in 1979 .

\subsubsection{Fuel Consumption Demand, 2000}

The OTA scenarios will also be used to project fuel consumption. In Case $A$, diesel-powered automobiles are assumed to be $10 \%$ of new car sales in 1985 and 25\% of new car sales in 2000. The EPA fleet fuel economy standard is assumed to rise to $27.5 \mathrm{mpg}$ by 1985 and remain constant until 2000. In Case $B$, diesel engines are assumed to capture 15\% of new car sales in 1985 and 40\% by 2000. The EPA fleet fuel economy standard is assumed to increase from $27.5 \mathrm{mpg}$ in 1985 to $35.0 \mathrm{mpg}$ in 2000 .

For Case A, the projected automobile gasoline consumption in 2000 is 56.4 billion gallons, or 7.05 quads of gasoline energy. In Case $B$, the projected consumption is 42.9 billion gallons, or 5.36 quads.

\subsection{SERVICE ACTIVITY LEVEL}

\subsubsection{Service Activity Level, 1980}

In 1980, automobiles traveled 1.112 trillion miles, accounting for $83 \%$ of the total number of vehicle-miles traveled (VMT) in the transportation sector (Millar et a1. 1982, Oak Ridge 1981). On the average, each auto traveled 10,600 miles. Automobiles carried passengers a total of 2.113 trillion miles, accounting for $74 \%$ of the domestic passenger miles traveled (PMT), and consumed $75 \%$ of the energy used in domestic passenger travel. The load factor for local travel was 1.87 and for intercity travel was 1.96 .

These figures can be translated to engine load-miles to provide a measure of the work being performed by the engine. In 1980, the curb weight of the average automobile was 3363 lb (see Table 1.1). If a typical load factor was 1.9 for passengers (averaging $150 \mathrm{lb}$ ) and a typical cargo weight was $50 \mathrm{lb}$, the average gross weight totals to $3698 \mathrm{lb}$. This weight multiplied by the 
approximately 1.112 trillion miles traveled by automobiles yields a value of 2.06 trillion ton-miles, or 19,700 ton-miles per vehicle.

\subsubsection{Service Activity Level, 2000}

An average of the forecasts mentioned earlier indicates that the number of vehicle-miles traveled in 2000 will increase to 1.69 trillion miles. The average annual VMT is forecasted to increase slightly, to 12,100 mi les. In Scenario $A$, approximately $80 \%$ of the automobiles are gasoline-powered and in Case $B$, 69\% of the automobiles use gasoline. Unfortunately, the OTA assumptions regarding changes in the average weight of the vehicles in both scenarios were not presented. However, a minimal average weight reduction of $500 \mathrm{lb}$ seems reasonable and will be used for the Scenario A approximation. Assuming that much of the improvement in gasoline fuel economy for Scenario B will also be attributable to weight reduction, the average weight will be further reduced to $2360 \mathrm{lb}$. Assuming the passenger and cargo loads remain relatively unchanged, the engine load-miles can be approximated as 1.91 trillion ton-miles $(17,300$ ton-miles per vehicle) for Scenario $A$ and 1.37 trillion ton-miles $(14,300$ tonmi les per vehicle) for Scenario $B$. 


\section{REFERENCES}

ARGOS Associates, Inc. 1978. Automotive Applications of Composite Materials. Winchester, Massachusetts.

Cummings-Saxon, J. 1981. Automobile Materials Competition: Energy Implications of Fiber Reinforced Plastics, Argonne National Laboratory, Argonne, Illinois.

Energy Resources Counci1. 1976. The Report by the Federal Task Force on Motor Vehicle Goals Beyond 1980. Washington, D.C.

Holland, M. S. 1977. "Use of Magnesium in Automobile," presented at the M.I.T. International Conference on Energy Conservation in Production and Utilization of Magnesium.

Hopp, W., et al. 1981. Overview of Energy Conservation Research Opportunities. PNL-3944, Pacific Northwest Laboratory, Richland, Washington.

Hsia, H. 1981. Weight Reduction Potential of Automobiles and Light Trucks, 1980 Summary Source Document, U.S. Department of Transportation, Research and Special Programs Administration, Transportation Systems Center, Cambridge, Massachusetts.

Imhoff, C. H., A. Liberman and W. B. Ashton. 1982. U.S. Energy Conversion and Use Characteristics. PNL-4075, Pacific Northwest Laboratory, Richland, Washington.

Jet Propulsion Laboratory. 1975. Should We Have a New Engine? JPL SP43-17. Pasadena, California.

Kenney, G. B., et al. 1980. "An Assessment of the Potential for Magnesium Penetration of the U.S. Automotive Market," presented at the 37th International Magnesium Association Conference, Salt Lake City, Utah.

Knorr, R. and M. Millar. 1979. Projections to Automobile, Light Truck, and Bus Stocks and Sales, to the Year 2000. ANL/CNSV-TM-22, Argonne Nationa 1 Laboratory, Argonne, Illinois.

Kulkarni, S. V. 1982. Potential of Composite Material in Surface Transportation Applications. Lawrence Livermore Laboratory, Livermore, California.

MVMA Motor Vehicle Facts and Figures. 1982. Motor Vehicle Manufacturer's Association of the United States, Inc., Detroit, Michigan.

Millar, M. et aT. 1982. Baseline Projections of Transportation Energy Consumption by Mode: 1981 Update. ANL/CNSV-28, Argonne National Laboratory, Argonne, IlTinois. 
Oak Ridge National Laboratory. 1981. Transportation Energy Conservation Data Book: Edition 5, ORNL-5765, Oak Ridge National Laboratory, Oak Ridge, Tennessee.

Paul, D. S. 1979. "Requirements for Acceptance of Innovative New Materials in Motor Vehicle Applications," presented at the Conference on Basic Research Directions for Advanced Automotive Technology, Boston, Massachusetts.

U.S. Department of Transportation. 1979. Proceedings: Conference on Basic Research Directions for Advanced Automotive Technotogy, Boston, Massachusetts.

U.S. Office of Technology Assessment. 1979. Technology Assessment of Changes in the Future Use and Characteristics of the Automobile. Transportation System, Volume Il, Technical Report. Washington, D.C.

Ward's Automotive Yearbook. 1980, 1981 and 1982. Ward's Communication, Inc., Detroit, Michigan.

Zub, R. W., et al. 1980. Potential of Spark Ignition Engine, Ef fect of Vehicle Design Variables on Top Speed, Performance, and Fuel Economy, U.S. Department of Transportation, Research and Special Programs Administration, Transportation Systems Center, Cambridge, Massachusetts. 


\section{DISTR IBUT ION}

No. of

Copies

OFFSITE

6 M. E. Gunn

CE -142

U.S. Department of Energy

1000 Independence Avenue

Washington, DC 20585

$6 \mathrm{~J} . \mathrm{J}$. Eberhardt

CE-142

U.S. Department of Energy

1000 Independence Avenue

Washington, DC 20585

6 T. Levinson

CE-142

U.S. Department of Energy

1000 Independence Avenue

Washington, DC 20585

27 DOE Technical Information Center

6 R. 8. Abarcar

Energetics, Inc.

9210 Route 108

Columbia, MD 21045

T. T. Bramlette

Sandia Laboratories

P.0. Box 969

Livermore, CA 94550

J. A. Carpenter, Jr.

Oak Ridge National Laboratory

B1dg. 4508 Room 263

P.0. Box $X$

Oak Ridge, TN 37831

M. Clayton

Jet Propulsion Laboratory

4800 Oak Grove Drive

Mail Code 125-159

Pasadena, CA 91109
No. of

Copies

M. Dastoor

Jet Propulsion Laboratory

4800 Dak Grove Drive

Mail Code 122-123

Pasadena, CA 91109

T. M. Dyer

Sandia Laboratories

P.0. Box 969

Livermore, CA 94550

C. Fink

Energetics, Inc.

9210 Route 108

Columbia, MD 21045

R. E. Holtz

Argonne National Laboratory

9700 South Cass Avenue

Building 330

Argonne, IL 60439

S. Hsu

National Bureau of Standards

Bldg. 22D Room A-215

Washington, DC 20234

M. Kaminsky

Argonne National Laboratory

9700 South Cass Avenue

Argonne, IL 60439

K. G. Kreider

Nationa! Bureau of Standards

Physics Building B-50

Washington, D.C. 20234

R. Phen

Jet Propulsion Laboratory

4800 Oak Grove Drive

Pasadena, CA 91109 
No. of

$\underline{\text { Copies }}$

C. W. Robinson

Sandia Laboratories

P.0. Box 969

Livermore, CA 94550

A. Schaffhauser

Dak Ridge National Laboratory

Bldg. 4508 Mailcode 110

P.0. Box X

Oak Ridge, TN 37830

X. Snith

Albuquerque Operations Office P.0. Box 5400

Albuquerque, NM 87185

W. H. Thielbahr

Idaho Operations Office

550 Second Street

Idaho Falls, ID 83401
No. of

Copies

ONSITE

DOE Richland Operations Office

H. E. Ransom

D. R. Segna

38 Pacific Northwest Laboratory

W. B. Ashton

D. L. Brenchley

A. D. Chockie

J. E. Danko

R. A. Hutchinson

C. H. Imhoff

D. R. Johnson (24)

J. $X$. Young

Publishing Coordination MA (2)

Technical Information (5) 